\title{
Behandlingen af unge stofmisbrugere
}

\section{Af klinikchef, cand. psych. KAREN BERNTSEN, K $\phi$ benhavn}

Vi har i mange år haft og vi har stadig et alkoholproblem, som vi har fors $\phi$ gt at angribe på forskellige måder gennem lovgivningen, gennem skatter og afgifter, ved tvangsmæssige foranstaltninger, behandlingsmæssige tilbud, medicamentel behandling, sociale foranstaltninger, psykologisk og psykiatrisk hjælp og gennem forskellige former for organisationer som afholdsbevægelsen „Blå Kors“ og „Læænken“ eller „Ring i Ring“, der svarer til den amerikanske Alcoholic Anonymous (AA) bevægelse.

Men til trods for alle anstrengelser og bestræbelser er vi ikke kommet alkoholproblemerne til livs, vi har derimod lært at leve med den. Alkohol indgår som en del af vor kultur, den er et socialt accepteret nydelsesmiddel, som vi relativt tidligt i livet lærer at omgås på en rimelig måde. Men vi ved også, at prisen for, at flertallet af samfundsborgerne kan have glæde af vin, $\varnothing \mathrm{l}$ og spiritus, er at et mindretal bliver drikfældige eller alkoholister. Dette mindretal er af en ganske betydelig størrelse, i Danmark regner man med, at der findes ca. 90.000 voksne personer, der på en eller anden måde burde under behandling for alkoholmisbrug.

Et andet misbrugsproblem, som findes i vort samfund, angår det meget store forbrug af forskellige former for de såkaldte ,nervepiller" og sovemedicin, men heller ikke dette problem er genstand for særlig stor opmærksomhed eller interesse fra offentlighedens side.

For både alkohol- og for medicinmisbrugets vedkommende kan dette skyldes, at misbrugerne for størstepartens vedkommende er personer over 30 år, oftest midaldrende mænd og kvinder.

Det misbrugerproblem, der derimod har været genstand for st $\varnothing$ rst opmærksomhed og til tider stærkt sensationspræget interesse, drejer sig om brug og misbrug af euforiserende stoffer og narkotika blandt unge mennesker.

En af grundene til denne opmærksomhed er utvivlsomt, at det er unge i alderen $14-21$ år, der bliver narkomaner eller stofmisbrugere. En anden grund er, at stofmisbruget umiddelbart synes at medf $\varnothing$ re alvorlige konsekvenser ikke alene i form af fysiske svækkelsestilstande og legemlige sygdomme, men også i form af psykiske lidelser, kortvarige eller længerevarende psykoser og personlighedsmæssige forandringer og $\mathrm{i}$ form af kriminel og asocial levevis.

Omfanget af de unges brug og misbrug af euforiserende stoffer og narkotika er fors $\varnothing$ gt belyst gennem forskellige unders $\phi$ gelser foretaget på initiativ af „Kontaktudvalget vedrørende ungdoms- 
narkomani“. Det fremgår af en redeg $\varnothing$ relse fra $1972^{1}$ ), at ca. $2 / 3$ af unge i alderen 14-20 år i K $\phi$ benhavn formodentlig har pr $\phi$ vet at ryge hash, og at det kan formodes, at samtlige unge i l $\phi$ bet af et par år vil have prøvet at ryge hash.

Misbrugsmønstret har i de forl $\varnothing$ bne år, fra omkring 1966-67 til 1973 gennemgået en vis udvikling. I de første år, til omkring 1969, var de foretrukne stoffer hash, LSD, mescalin og andre hallucinogene stoffer. Stofbruget forekom dengang ofte at være en del af „hippiekulturen“, og de unge misbrugere syntes at være mindre socialt og psykisk belastede og mindre behandlingstrængende end det senere klientel.

Fra omkring 1969 var det stort set opiaterne, der vandt indpas, f $\phi$ rst $\mathrm{i}$ form af opium, morfinklorid, tetrapon etc. og fra omkring 1971 hovedsagelig den meget kraftige morfinbase, der i styrke og farlighed kan sidestilles med heroin. Samtidig synes misbrugerklientellet i disse år at have ændret sig, de er i langt højere grad socialt og psykisk belastede, har færre resourcer og kræver en mere nuanceret og længerevarende behandling end tidligere.

Misbruget i Sverige har i overvejende grad koncentreret sig om de centralstimulerende stoffer, specielt amfetaminerne, medens det i Norge hovedsageligt har drejet sig om misbrug af hash, LSD $o g$ indsnusning af fortyndervæske (glue-sniffing).

Det må dog tilføjes, at de fleste egentlige stofmisbrugere har prøvet alle de her nævnte præparater foruden sovemidler og nervepiller.

Med hensyn til hvor mange unge der i Danmark er ude i et så alvorligt misbrug, at de er behandlingskrævende, findes der ikke klare oplysninger herom, men de forskellige sk $\phi$ n ligger fra 6.000 til 10.000 i hele landet. Der er således klart tale om et alvorligt problem, selvom det st $\varnothing$ rrelsesmæssigt ikke nær er af samme omfang som vort alkoholproblem.

Den store interesse for ungdomsnarkomani eller stofmisbrug har givet sig udtryk på flere andre planer. Her kan blandt andet nævnes, at Folketinget i 1969 nedsatte et specielt udvalg (Folketingets narkotikaudvalg), hvor samtlige politiske partier var repræsenteret. Dette udvalg med skiftende formænd og skiftende repræsentanter skulle planlægge og gennemf $\varnothing$ re landets narkotikapolitik og samtidig medvirke ved fordelingen af de $\phi$ konomiske resourcer.

Dette udvalg blev imidlertid nedlagt i 1972, idet narkotikaproblemet blev overført til Folketingets sociale udvalg. Der var en del uenighed med hensyn til det hensigtsmassige i denne dispo-

1) Erik Manniche, Bjørn Evald Holstein og Merete Watt Boolsen: En empirisk og teoretisk analyse af stofbrug blandt unge på Bornholm 1972. 
sition. På den ene side blev det og kan det stadig g $\phi$ res gældende, at ungdomsnarkomani skal behandles på linje med andre sociale problemer og ikke indtage en særlig plads, hvorved både diskussioner og dispositioner kan blive mindre sensationsprægede og måske i ringere grad politisk sprængstof. På den anden side kan det diskuteres, om der ved denne overf $\phi$ relse er større risiko for, at det bliver vanskeligere at planlægge og gennemf $\varnothing \mathrm{re}$ en egentlig narkotikapolitik, samt for at den så længe savnede udbygning af foranstaltninger indenfor forebyggelse, behandling og efterbehandling vil træde i baggrunden.

I 1969 nedsattes et andet udvalg „Kontaktudvalget vedr $\phi$ rende ungdomsnarkomani“", bestående af repræsentanter for indenrigsministeriet, justitsministeriet, socialministeriet, undervisningsministeriet, udenrigsministeriet og finansministeriet samt sundhedsstyrelsen og af psykiatriske sagkyndige. Udvalgets opgave var og er stadig at være rådgivende organ ved tilrettelæggelse og koordination af de forskellige foranstaltninger for bekæmpelse af stofmisbrug blandt unge samt at f $\varnothing$ lge udviklingen, blandt andet ved at iværksætte sociologiske og socialmedicinske unders $\phi$ gelser.

Stofmisbrugerproblematiken forudsættes således at indeholde aspekter, der berører de fleste grene af administrationen, ligesom mange forskellige faggrupper beskæftiger sig med emnet. Selvom emnet nu er overf $\varnothing$ rt til folketingets sociale udvalg, hører det i dag under indenrigsministeriets fagområde, det vil sige, at det er placeret som et lægeligt problem. Dette skal dog kun forstås således, at det er indenrigsministeriet, der skal koordinere arbejdet med de $\varnothing$ vrige fagministerier.

De fleste af de euforiserende og narkotiske stoffer, det drejer sig om med hensyn til ungdommens stofmisbrug, er enten indført illegalt til landet, eller de er erhvervet på illegal vis, f. eks. ved indbrud, ved receptforfalskning eller lignende.

Der findes en særlig lov om euforiserende stoffer, der bemyndiger indenrigsministeren til at bestemme, at stoffer, der frembyder særlig fare på grund af deres euforiserende egenskaber, ikke må forefindes i landet, medens andre kun må anvendes i medicinsk eller videnskabeligt $\phi$ jemed. De f $\varnothing$ rstnæunte stoffer omfatter blandt andet heroin, råopium og cannabis, der er opf $\varnothing$ rt på liste A i bekendtg $\phi$ relse af 17. november 1969.

Der har været en del diskussion og stærkt delte meninger om det rimelige $\mathrm{i}$, at cannabisprodukterne blandt andet hash er opf $\varnothing$ rt på liste $\mathrm{A}$, idet det har vist sig, at det tilsyneladende er det lettest tilgængelige stof, det mest anvendte og vel også på mange måder det mindst „farlige“" stof.

Der er noget paradoksalt $\mathbf{i}$, at man på den ene side betragter cannabisprodukterne som så skadelige, at de ikke er tilladt i landet, når man på den anden side gennem forskellige undersøgelser 
har erfaret, at en så stor procentdel af unge i alderen $14-18$ år har prøvet at ryge hash.

Narkotikakriminaliteten er i Danmark henlagt til drabsafdelingen, og der er i København blandt andet oprettet en speciel „uropatrulje“, hvis opgave det er at arbejde på gadeplanet og f $\varnothing$ lge udviklingen i stofudbredelsen og i stofmisbrugerkredse.

Den linje, der er lagt vedrørende den politimæssige side, har været gennem efterforskningen at finde frem til de egentlige storforhandlere af narkotika, kun at interessere sig for småforhandlerne og de unge stofmisbrugere $\mathrm{i}$ det omfang disse kunne give politiet oplysninger om de næste led i forhandlerkæden.

Dette har imidlertid vist sig at være en meget vanskelig opgave og et uhyre mandskabs- og tidskrævende arbejde, og kun i de færreste tilfælde kan det siges, at man virkelig har opnået at bryde en sådan kæde op. Men det lykkedes dog tilsyneladende i forsommeren 1972, hvor der blandt andet blev konfiskeret 127 kg morfinbase. Et sådant politimæssigt „kup“ kunne mærkes føleligt på stofmarkedet, der blev ,tørke“, og dette bevirkede igen, at der opstod panik i misbrugerkredsene. Det meget ringe udbud af morfinbase bevirkede en forrygende prisstigning, men samtidig begyndte stofmisbrugerne $\mathrm{i}$ h $\phi$ jere grad at anvende barbiturater og andre stoffer, som på sin vis havde skadeligere virkning end basen.

En anden ting g $\phi \mathbf{r}$ sig gældende vedrørende politiets arbejde og direktiverne herfor. På papiret kan der skelnes mellem forhandlere og forbrugere, men $\mathrm{i}$ praksis er det som regel en og samme person. En stofmisbruger, der vil eller skal have morfinbase eller andre lignende stoffer hver dag, kan som regel ikke skaffe penge til sit stof uden at begå kriminalitet, og det mest almindelige i den forbindelse vil være, at han må sælge stoffer for at skaffe sig sin daglige dosis. Hvor ligger nu græensen for, om man skal betragte ham som forhandler eller forbruger?

Der er for $\phi$ vrigt givet visse direktiver med hensyn til dette spørgsmål i rigsadvokatens cirkulære af 15 . juli 1969 , der har gennemgået en mindre revision i august 1971.

\section{I cirkulæret udtales:}

„Der vil i reglen ikke være anledning til at indlede undersøgelse med henblik på at pålægge strafansvar for besiddelse (køb eller modtagelse), når mistanken alene angår eget forbrug af euforiserende stoffer. I overensstemmelse hermed $b \phi r$ der vises tilbageholdenhed med af egen drift at indlede undersøgelse f. eks. på skoler, selvom politiet får formodning om, at der er konstateret misbrug af euforiserende stoffer.

Konstaterer politiet forbrug af euforiserende stoffer, b $\phi \mathbf{r}$ det dermed forbundne strafansvar for besiddelse ( $k \phi b$, modtagelse) i reglen afg $\phi$ - 
res med, at der meddeles den pågældende en advarsel af politiet. Advarsel vil også kunne meddeles $\mathrm{i}$ gentagelsestilfælde, men i grovere gentagelsestilfælde, og i tilfælde af gentagen besiddelse af andre euforiserende stoffer end hash $b \phi \mathbf{r}$ der s $\varnothing$ ges pålagt b $\phi$ destraf. I forbindelse med meddelelsen af en advarsel eller pålæg af bøde vil der efter en bedømmelse i hvert enkelt tilfælde kunne være anledning til at henvise den pågældende til behandling, for så vidt der på stedet er etableret behandlingscenter for narkotikamisbrug.

Består overtrædelsen alene $\mathrm{i}$ besiddelse af euforiserende stoffer $\mathrm{i}$ forbindelse med eget brug, bør der således i reglen ikke nedlægges påstand om betinget dom, heller ikke i gentagelsestilfælde, eller udfærdiges tiltalefrafald med vilkår om børne- og ungdomsforsorg, men er lovovertræderen under 18 år, underrettes børne- og ungdomsværnet om sagen og om den afgørelse, som er truffet. ,

Skal der rejses tiltale for andre forhold, $b \phi r$ forhold, der alene angår besiddelse i forbindelse med eget forbrug, ikke medtages særskilt i tiltalen. Findes nogen i ulovlig besiddelse af euforiserende stoffer, s $\phi$ ges beholdningen beslaglagt og konfiskeret."

H. H. Brydensholt fremhæver i „Narkotika og Straf" side 85: ,For en umiddelbar betragtning kan det forekomme ejendommeligt, at man har opretholdt en formel kriminalisering af de blotte brugere (besiddelse, $k \phi b$, modtagelse), når realiteten dog er, at man ikke vil gennemf $\phi$ re en sædvanlig retsforf $\varnothing$ lgning. Det er klart uheldigt, at lovens ord ikke dækker denne faktiske retstilstand".

Vedrørende lovbestemmelser om straf for narkotikakriminalitet gjaldt indtil 1969 udelukkende loven om euforiserende stoffer, hvorefter overtrædelse kunne straffes med bøde, hæfte eller fængsel i indtil 2 år.

På dette tidspunkt skærpedes straffene, idet der ved lov af 18 . juni 1969 indførtes en ændring i borgerlig straffelov $\S 191$, der vedrørte de mere professionelle narkotikaforhandlere. Straframmen blev her forøget til 6 år, hvorved den blev bragt på linje med Sveriges og Norges strafferammer. I Danmark er maksimumstraffen uændret 6 år, medens Sverige og Norge i 1972 har forh $\phi$ jet den til 10 år.

Der er ikke i denne artikel plads til at uddybe problemerne omkring politiets arbejde og domstolenes praksis, men der må her henvises til de forskellige redeg $\varnothing$ relser og bøger, der er udgivet om emnet, specielt H. H. Brydensholt: "Narkotika og Straf“.

Når der opstår et nyt problem i et samfund, som kræver, at der på en eller flere måder må tages stilling til, hvilke foranstaltninger der skal iværksættes, for dels at undgå at problemet vokser i udstrækning, dels at hjælpe de personer der tilsyneladende ikke 
selv kan klare deres aktuelle situation, kan man gribe spфrgsmålet an på flere måder.

Og dette er da også fors $\varnothing$ gt med hensyn til ungdommens stofmisbrug.

Den ene linje har været gennem for $\varnothing$ get politiindsats og skærpet kontrol fra toldvæsenets side at fors $\phi$ ge at forhindre indf $\varnothing$ rsel og distribution af de illegale stoffer. Selvom disse foranstaltninger kan have en vis effekt, er der vel en berettiget tvivl om, at problemerne kan loses ad denne vej. Det er naturligvis rigtigt, at der ikke ville eksistere et ,stofproblem“, hvis de pågældende stoffer ikke fandtes eller ikke var tilgængelige. Men da der vel stort set er enighed om, at det problem, vi har med at gøre, ikke kan betragtes som et isoleret stoffænomen, men er et langt mere kompliceret fænomen, der drejer sig om de samfundsmæssige betingelser, de sociale forhold og de psykiske ejendommeligheder hos en relativt stor gruppe unge, så vil vi stadig have problemerne også uden de pågældende stoffers tilstedeværelse.

Den anden linje er anvendelsen af strafferetlige sanktioner over for de enkelte personer, som overtræder reglerne. Oven for er nærmere redegjort for udviklingen inden for dette område. Her skal blot bemærkes, at der har været rejst alvorlig kritik over for de ofte meget langvarige varetægtsfængslinger, der anvendes over for unge stofmisbrugere. Hensigtsmæssigheden i anvendelse af fængselsstraffe over for den samme gruppe er også til stadighed til debat.

I praksis har det vist sig, at end ikke det stærkt sikrede og lukkede fængselsmilj $\varnothing$ har kunnet holdes stoffrit, hvilket if $\varnothing$ lge fortalerne for tvangsforanstaltninger angives som en nødvendighed

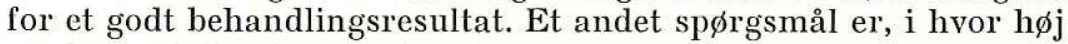
grad resocialiseringsmulighederne hæmmes af den stempling som kriminel, der f $\varnothing$ lger af retssagen, dommen og strafafsoningen, når den eller de lovovertrædelser, der d $\phi$ mmes for, er direkte eller indirekte forbundet med den pågældende persons stofmisbrug.

Den tredje linje har været at finde frem til en rimelig behandlingsmæssig politik. Jeg skal ikke her komme nærmere ind på den ofte stærkt f $\varnothing$ lelsesladede og til tider meget usaglige debat, der har været ført offentligt om behandling på tvangsmæssig contra frivillig basis. Det er en debat, der i $\varnothing$ jeblikket ikke synes at være aktuel, dels fordi der både fra politisk side og fra den brede offentlighed er andre og mere presserende problemer til diskussion, som landets $\phi$ konomiske situation, tilslutningen til det europæiske fællesskab og forureningsspørgsmål, og dels fordi planerne om etablering og udbygning af foranstaltninger til forebyggelse og behandling af stofmisbrugsproblemerne nu er overtaget af de amtskommunale sociale udvalg i forbindelse med socialreformen i Danmark. 
Det kan dog nævnes, at der både fra politikernes side og fra den behandlingsmæssige sagkundskabs side ikke har været flertal for en udvidelse af de tvangsmæssige foranstaltninger. Man er stort set enige om det hensigtsmæssige i at udbygge behandlingskæder, som skal omfatte forskellige faser $\mathrm{i}$ et behandlingsforl $\phi \mathrm{b}$ : 1. Det ops $\varnothing$ gende og motiverende arbejde. 2. Den begyndende behandling med nedtrapning eller afgiftning. 3. Den videre behandling med vægten lagt på at gøre de pågældende funktionsduelige i social og psykisk henseende og 4 . En efterbehandling inden en mulig udslusning i normalsamfundet.

Denne model svarer stort set til det, der er fors $\phi$ gt opbygget inden for Ungdomsklinikens behandlingseksperiment i K $\phi$ benhavn, et eksperiment der blev iværksat i foråret 1969, og vel var det f $\emptyset$ rste fors $\varnothing \mathrm{g}$ på at etablere et system, der i sig selv skulle indebære mulighederne for at føre en stofmisbruger igennem fra et gadeplansniveau til vedkommende var stærk nok til at klare sig ude i samfundet.

Da der nu er gået ca. 4 år siden dette eksperiment blev påbegyndt, ville det da være rimeligt at fors $\phi$ ge at fremlægge nogle af de erfaringer, der er indhentet i den forl $\phi$ bne tid.

Umiddelbart ville det forekomme naturligt, om det kunne være resultaterne af arbejdet, der blev fremlagt. Dette er imidlertid ikke muligt af følgende grund. Til det nævnte behandlingseksperiment er knyttet et forskningsprojekt, der er overgivet til Mentalhygiejnisk Forskningsinstitut under ledelse af direkt $\phi r$, dr. phil. Eggert Petersen. Forskningsinstituttet har afsluttet indsamlingen af materialet og vil pr. 1. juli 1973 fremlægge deres resultater i form af en forskningsrapport. Denne vil blandt andet indeholde en beskrivelse af behandlingssystemet og dets udvikling $\mathrm{i}$ den forl $\phi$ bne tid, en beskrivelse af klientellet, stofmisbruget og dets art og omfang samt den sociale baggrund og belastning samt en extensiv og intensiv efterunders $\phi$ gelse af det senere forl $\phi \mathbf{b}$. Den sidste del omfatter således en opg $\varnothing$ relse af resultaterne, en effektivitetsunders $\varnothing$ gelse, som antagelig i dette tilfælde som i de fleste andre behandlingseksperimenter, hvor dette er fors $\phi \mathrm{gt}$, vil være uhyre vanskelig at vurdere. Om resultatet kan vurderes som positivt eller negativt må afhænge af forventningsniveauet, som f. eks. kan være vidt forskelligt i de forskellige faggrupper, i de forskellige politiske kredse og i befolkningen.

Som det er fremgået af ovenstående, er det således ikke resultater, men personlige erfaringer og synspunkter, erhvervet gennem disse 4 års arbejde med unge stofmisbrugere i København, jeg her vil fremføre. Men for at undgå misforståelser må jeg straks tilf $\varnothing j e$, at mine betragtninger ikke bygger på praktisk behandlingsarbejde med det enkelte individ, idet dette ikke har været muligt samtidig med, at et system har skullet opbygges, 
når ledelsen kun har bestået af to personer: ledende psykolog John Andersson og mig selv.

Ungdomskliniken og det dertil knyttede dag- og døgncenter, der blev oprettet af $\phi$ konomiske og formelle grunde med henblik på behandlingseksperimentet med unge stofmisbrugere, har til stadighed fastholdt det princip, at behandlingen må ske på frivilligt grundlag, at klienterne $\mathrm{i}$ så vidt omfang som muligt skal gøres ansvarlige og træffe deres eget valg, at afstanden mellem behandler og klient skal gøres så lille som muligt, at der skal være flere og forskelligartede tilbud for stofmisbrugere på forskelligt trin og på forskelligt stadium, samt at målet med arbejdet må være at få den enkelte stofmisbruger til at ophøre med det misbrug, der antagelig vil фdelægge ham/hende fysisk, psykisk og socialt. Eller i hvert fald gøre ham så stærk, at han har en rimelig mulighed for at træffe et valg for sin fremtid.

Her kan det være hensigtsmæssigt at fremkomme med nogle enkelte bemærkninger og standpunkter til den debat, der i den senere tid er f $\varnothing$ rt vedr $\phi$ rende methadonvedligeholdelse. I betragtning af stofmisbrugerklientellets unge alder og $\mathrm{i}$ betragtning af de få år problemet har eksisteret i hvert fald i Danmark, og endelig i betragtning af, at intet behandlingssystem har haft de $\phi \mathrm{ko}-$ nomiske resourcer, den tilstrækkelige dækning af personalemæssig erfaring og sagkundskab, bør man være meget varsom med at anbefale en sådan løsning på problemet. Det er indlysende, at det vil være den billigste og mindst belastende $1 \phi$ sning samfundsmæssigt at sætte en vis gruppe af unge stofmisbrugere på en fast methadonvedligeholdelsesdosis. Det er da muligt, at den kriminelle aktivitet nedsættes, $\mathrm{i}$ hvert fald $\mathrm{i}$ en periode, og det er også muligt, at de pågældende vil blive $\mathrm{i}$ stand til at fungere socialt på en mere hensigtsmæssig måde. Problemet er imidlertid, hvordan man får et sådant system under kontrol, og her bør man lære af erfaringerne fra U.S.A. og også fra England. Det er efter min mening en meget farlig vej at gå på det aktuelle udviklingstrin i stofproblematiken. Det er muligt, at vi om nogle år har større mulighed for at vurdere og tage stilling til en antagelig talmæssig ganske lille gruppe stofmisbrugere, der på grund af blandt andet psykiske belastninger og personlighedsmæssige afvigelser ikke kan klares ad behandlingsmæssig vej og ikke holder op med stofferne spontant. Kommer vi dertil, kan spфrgsmålet tages op igen.

Dette var et sidespor, som ikke havde noget at gøre med det centrale problem i denne artikel, nemlig erfaringerne med behandlingen af unge stofmisbrugere, med udgangspunkt i Ungdomsklinikens eksperiment.

Det f $\not r$ rste trin er kontaktfasen, som enten kan ske gennem et ops $\varnothing$ gende arbejde på steder, hvor stofmisbrugerne holder til, 
eller ved at etablere steder på ,gadeplansniveauet“. Et fors $\phi g$ på det ops $\phi$ gende arbejde i marken er foretaget af Statshospitalet i Glostrups misbrugerprojekt (Program 117), der fra januar 1971 har haft et opsøgende team bestående af én psykolog og to socialrådgivere. Dette team har dels arbejdet gennem amtets forskellige sociale institutioner, dels arbejdet på det egentlige gadeplan. Begrundelsen for arbejdet har været dels at give de unge misbrugere information om, hvilke behandlingsmuligheder der fandtes, dels at sikre, at det var de mest motiverede og mest trængende misbrugere, der kom ind i hospitalets behandlingsprogram (se i $\phi$ vrigt bilag 7 i Kontaktudvalget vedr $\varnothing$ rende ungdomsnarkomani : Redeg $\phi$ relse III om Prævention af Stofmisbrug).

I Ungdomsklinikens behandlingseksperiment er der ikke foregået en direkte ops $\varnothing$ gende virksomhed, idet der allerede i 1969 blev etableret et kontaktcenter, der var åbent for alle stofmisbrugere, dog hovedsageligt de hårdest ramte, ,,junkierne“. Det f $\phi$ rste kontaktcenter måtte lukke januar 1972, da huset skulle saneres. Det nye kontaktcenter, som blev åbnet februar 1972, er beliggende på et stærkt trafikeret str $\varnothing$ g. Det er betydligt st $\phi$ rre end det gamle, det er faktisk for stort og har på en del punkter vist sig uegnet. Det er vanskeligt for personalet at få en bæredygtig kontakt med stofmisbrugerne på stedet, personalegruppen har måttet udvides for blot at udføre kontrolfunktionerne, omkostningerne for for store, og beliggenheden uheldig. Det mest uheldige er, at kontaktcentret er blevet en for stor indgangsport i systemet, idet det er umuligt for personalegruppen at få mere en br $\phi k d e l$ af de over 1.000 personer, der i l $\phi$ bet af et år går igennem kontaktcentret, i en egentlig behandling. Og da Ungdomskliniken også er indgangsport, og der også modtages stofmisbrugere gennem henvisninger eller fra gaden, bliver den næste fase en ,flaskehals". Det er derfor hensigten så hurtigt som muligt at lukke det store kontaktcenter og i stedet oprette et lille eller 2 små kontaktcentre, hvor mulighederne for at lære en mindre gruppe bedre at kende og gennemf $\varnothing$ re en motivationsproces skulle være større.

Som nævnt er en anden indgangsport Ungdomskliniken, der ikke er noget „,værested“, men hvor man m $\varnothing$ der spontant eller efter aftale, på eget initiativ eller efter henvisning fra kontaktcentret, fra lægelige eller sociale institutioner. Der sker her en slags visitation, idet socialrådgiveren eller psykologen gennem den eller de første samtaler pr $\varnothing$ ver at finde det mest hensigtsmæssige behandlingstilbud til den pågældende. Der lægges vægt på at få overblik over stofsituationen, stofmisbrugets art, grad og længde, over den aktuelle sociale og psykiske tilstand, uddannelses- og arbejdsmæssige forhold, bopælssituationen, tidligere funktionsniveau, nuværende tilknytninger til ikke-stofbrugende contra 
stofbrugende personer eller kredse. Der fors $\phi$ ges for $\phi$ jeblikket indarbejdet en mere systematisk dataindsamling på grundlag af et fra amerikansk oversat skema, der bygger på ovennævnte oplysninger og sætter disse i relation til behandlingsmetodiker af forskellig intensitet og varighed. (Stephen M. Pittel og Ricardo Hofer: Et fors $\emptyset \mathrm{g}$ på systematisering af visitation af stofmisbrugere til forskellige behandlingstilbud.)

Der er nu etableret forskellige behandlingsformer på Ungdomskliniken, som kun skal groft skitseres:

1. Familiebehandling. En sådan vil fors $\phi$ ges iværksat, når den unges stofmisbrug endnu ikke har nået en sådan størrelse eller sådan art, at en egentlig nedtrapning eller afgiftning sk $\varnothing$ nnes nødvendig, når han/hun har bopæl hos og kontakt med forældre eller andre pårørende (f. eks. ægtefælle eller samlever), og når han/hun endnu fungerer nogenlunde socialt gennem arbejde, uddannelse, skole.

Kravet er, at hele familien er til stede ved samtalerne, og målet er at få hele familien til at fungere bedre, at kommunikere bedre, at få ændret en uhensigtsmæssig balance gennem selvindsigt og st $\varnothing$ rre forståelse. (Se litteraturlisten: Kempler - Perls - Satir).

2. Ambulant nedtrapning og gruppebehandling. Denne fors $\phi$ ges i tilfælde, hvor stofmisbruget er af en sådan størrelse, at en nedtrapning sk $\phi$ nnes n $\varnothing$ dvendig, men hvor det samtidig findes rimeligt, at den unge forbliver i sit normale miljø. Dertil kræves, at han/hun har nær forbindelse med en eller flere ikke-stofbrugende personer, der kan fungere som støtte for ham, ligesom det er hensigtsmæssigt, hvis han har en social funktion i form af uddannelse, deltidsarbejde eller lignende. Methadonnedtrapningen strækker sig her over relativ lang tid, 3-4 uger, og samtidig forsøger man at sammensætte en gruppe på $6-8$ stykker, der samles én gang ugentlig i ca. 2 måneder. Det synes at være et temmeligt vanskeligt projekt at gennemf $\varnothing$ re, og der er en del skepsis med hensyn til resultaterne. Det er imidlertid et fors $\varnothing$ g, som b $\phi r$ pr $\phi$ ves over et stykke tid, f $\phi \mathbf{r}$ der kan tages stilling til, om det skal opgives eller fortsætte.

3. Individuel behandling og individuelle ture. Der findes unge stofmisbrugere, som på forhånd synes uegnede til at kunne klare et gruppeforl $\phi \mathbf{b}$, og der findes andre, som uden godt resultat har fors $\phi$ gt at gennemf $\phi$ re de efterhånden nu traditionelle ture på landet, bestående af $6-7$ stofmisbrugere samt 2 medarbejdere.

Vi har her fors $\varnothing \mathrm{gt}$, om en længere tids individuel st $\varnothing$ ttebehandling, f. eks. over 1--2 måneder, uden hjælp af methadon men også uden egentlige krav om stofoph $\phi \mathbf{r}$, kan være af gavnlig betydning for den pågældendes holdning overfor og indstilling til sig selv, sine muligheder, sin situation. Hvis der sker noget i denne indledende periode, kan behandlingen fortsættes på en tur, hvor 
en medarbejder er alene med klienten. Her foregår da den egentlige methadonnedtrapning, samtidig med at den tætte kontakt skulle bringe klienten et stykke videre $\mathrm{i}$ form af st $\varnothing$ rre indsigt og bedre social funktion. Det videre forl $\phi b$ vil afhænge af systemets muligheder og klientens $\phi$ nsker og tilstand.

4. Turfunktionen. Der findes for $\varnothing$ jeblikket på Ungdomskliniken en turfunktion, idet der er ansat 12 unge medarbejdere til at varetage de specielle landture med nedtrapningsformål. De svarer til de ture, der tidligere blev varetaget af kontaktcentrets medarbejdere. Men dels $\emptyset$ nskede vi at udvide kapaciteten med hensyn til ture, og dels mente vi på et tidspunkt, at der var en gruppe stofmisbrugere, der var knapt så belastede, socialt, psykisk og stofmæssigt som kontaktcentrets klientel, og som derfor ikke krævede en så langvarig behandling som disse, hvorfor vi oprettede denne specielle funktion. Det har dog stort set vist sig, at dette ikke holder stik; de fleste af dem, som må fjernes fra miljøet og nedtrappes på landet, kan ikke klare sig blot med dette, men må fortsætte $\mathrm{i}$ andet behandlingsforl $\phi \mathrm{b}$, hvis de skal klare sig fremover i samfundet.

Og her er vi da ved det punkt, som for samtlige behandlingsystemer synes at være det vanskeligste.

Det forekommer ikke at være så svært at motivere stofmisbrugerne til at blive nedtrappet gennem en methadonbehandling. Naturligvis er det ikke altid lige let at gennemskue, hvad $\phi$ nsket om nedtrapningen står for. Det kan f. eks. skyldes, at man $\phi$ nsker at komme væk fra byen et stykke tid, fordi jorden brænder under fødderne, man har måske snydt kammeraterne, er bange for hævnaktioner, for politiet, eller måske trænger man blot til et pusterum, til at komme i en bedre fysisk kondition, f $\phi \mathrm{r}$ man fortsætter sit stofmisbrug. Det sker jævnligt, at en eller to forlader en tur, så snart den sidste methadondosis efter ca. 12 dages forløb er udleveret. Det spiller efter min mening ikke så stor rolle, når blot flertallet af gruppen forbliver på turen.

Men det stående problem og spørgsmål er: hvad skal der ske bagefter landturen? Vi kan også spфrge: hvad skal der ske på selve turen, og hvad skal der ske bagefter? Turene er oprindeligt tilrettelagt således, at de består af $6-7$ stofmisbrugere med 2 unge medarbejdere, der skifter hver 14. dag. Det egentlige formål er nedtrapning af stofferne (nu næsten altid morfinbase) ved hjælp af flydende methadonpræparat med daglige nedsatte doser over ca. 12 dage. Derudover er turen bygget op på at etablere en så normal levesituation som muligt, hvor medarbejdere og klienter efterhånden skal have samme ansvar og medbestemmelsesret. Turenes længde har varieret fra 1-4 måneder, men generelt synes det at være vanskeligt at fortsætte udover ca. 11/2 måned. Der har været problemer med de hyppige medarbejderskift, og der 
har været problemer med at skabe gunstige aktiviteter på turene, ligesom det tilsyneladende har været svært at gøre noget ved den enkelte klients personlighedsmæssige vanskeligheder.

Det er derfor nu fors $\varnothing \mathrm{gt}$ at arbejde med mindre grupper, f. eks. 4 klienter med 2 medarbejdere, der lever sammen i omkring en måned. Samtidig iværksættes nu en mere konsekvent og struktureret behandlingsmetodik ved hjælp af psykolog og socialrådgiver, begge trænede gruppebehandlere, der regelmæssigt bes $\varnothing$ ger turene.

Men tilbage står, hvad der skal ske bagefter?

I det sidste årstid har der faktisk kun eksisteret én mulighed, hvis klienterne ikke ville eller kunne klare at komme tilbage til K $\phi$ benhavn, og det var familiepleje på landet eller i en provinsby. Der er opbygget en speciel familieplejeafdeling på Ungdomskliniken, der fungerer godt, men som dels er utilstrækkelig, dels absolut ikke kan anvendes over for samtlige klienter.

En af grundene til denne situation er, at landets $\phi$ konomiske tilstand og de dermed f $\varnothing$ lgende spareforanstaltninger naturligvis også har kunnet mærkes inden for narkotikabehandlingen. Der kunne ikke ske nogen budgetudvidelse i finansåret 1972-73, der måtte arbejdes ud fra 1971 - 72 budgettet. Dette fik konsekvenser for de faciliteter, der var tænkt etableret i forlængelse af nedtrapningsturene, specielt fordi det dengang nyoprettede kontaktcenter var betydeligt dyrere end det gamle. Da situationen tilsyneladende vil blive den samme for finansåret 1973-74, har man derfor måttet foretage en prioritering af midlerne, således at der bliver mulighed for at etablere nogle faciliteter, der kan fungere i behandlingsforl $\phi$ bet efter nedtrapningsturene. De forel $\phi$ bige planer går ud på at oprette en slags aktivitets-h $\varnothing j$ skolecenter med plads til ca. 15 unge. Opholdets varighed kan variere fra 3-9 måneder, og der skal være mulighed for både at optrænes i og uddannes $\mathrm{i}$ manuelle færdigheder, forskellige former for håndværk og for optræning og uddannelse på mere intellektuelt plan. Det er ikke færdigdiskuteret, om centret skal fungere som et terapeutisk samfund eller mere som en skoleuddannelsesinstitution.

En anden nyskabelse skulle være to mindre "familiecentre“ beliggende i eller i udkanten af en større provinsby med gode arbejds- og uddannelsesbetingelser. Centrene skulle ledes af en pædagogfamilie, der havde ca. 4 stoffri klienter boende. De skal antagelig fungere på kollektiv basis, og kravet skulle være, at klienterne var $\mathrm{i}$ en arbejds- eller uddannelsessituation uden for huset men havde huset og gruppen som støttemiljø.

I København råder behandlingseksperimentet over en egen ungdomspension i en portbygning til det nedlagte $\emptyset$ stre Gasværk. Man har samtidig her fors $\phi$ gt at lave en klub, som dels skulle 
være åben for unge fra kvarteret, dels for stoffri klienter, som manglede et rimeligt fritidsmiljø. Klubben har imidlertid ikke fungeret, og der er nu planer om at omdanne lokalerne til et mindre, specielt indrettet revalideringsværksted.

Endelig kan nævnes den dagskole, som Ungdomskliniken etablerede $\mathrm{i}$ februar 1972. Der er her ansat 3 unge lærere, der kan tage sig af ca. 10 elever. Det har vist sig at være en fornuftig disposition, idet en meget stor del af de unge stofmisbrugere er interesseret $\mathrm{i}$ og trænger til at supplere deres skolekundskaber og almindelige viden, inden de er $\mathrm{i}$ stand til at f $\varnothing$ lge med enten på en almindelig folkehøjskole eller en højere skoleuddannelse.

Ungdomskliniken har tidligere, i 1968, 1970 og 1971, arrangeret forskellige former for „,minisamfund“. I det første deltog unge studerende og professionelt uddannede inden for forskellige fag. I de to næste deltog klienter og medarbejdere inden for systemet. Fremgangsmåden har været at dele deltagerne op i små levegrupper, og formålet har været at se, dels om disse levegrupper kunne komme til at fungere sammen på en sådan måde, at de dannede et samfund, dels at se om de enkelte levegrupper kunne bruge hinanden, eventuelt forkaste egne normer og overtage andre gruppers normer, der måske var mere hensigtsmæssige.

I marts 1973 er ideen med ,minisamfund“ påny blevet gennemprøvet på en noget anden måde. Den oprindelige tanke gik ud på at fors $\varnothing$ ge at få forskellige afvigergrupper sammen, f. eks. stofmisbrugere, alkoholister og trøstespisere. Udover disse grupper $\phi$ nskede vi at få en gruppe fra faglig ungdom samt et par „hjælpergrupper", det vil sige vore egne medarbejdere og b $\phi$ rneforsorgsstuderende. Med hensyn til de tre f $\varnothing$ rstnæunte grupper mener vi, at de alle pr $\phi$ ver at $1 \varnothing$ se deres problemer eller flygte fra dem på samme måde men ved hjælp af forskellige midler.

Spфrgsmålet måtte være, om de ville blive bedre i stand til at forstå deres egen problematik og gøre noget ved den ved at lære de andre grupper og deres problemer at kende. Gruppen faglig ungdom kunne være af værdi, fordi afvigergrupperne måske her igennem kunne lære at bruge et andet normsæt. Og endelig ville det være af værdi, at „hjælpergrupperne“ måske gennem minisamfundet fik noget mere indsigt i deres egen „hjælperrolle“. Det er blandt andet et sp $\phi$ rgsmål, som i den senere tid har været og er oppe til debat, nemlig i hvor h $\phi$ j grad behandlerne, „hjælper-

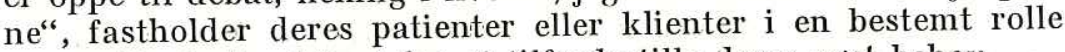
som patient eller klient for at tilfredsstille deres eget behov.

Minisamfundet kunne desværre ikke iværksættes efter den oprindelige plan, da det ikke lykkedes os at skaffe den overvægtige gruppe (trøstespiserne) og ej heller gruppen af faglig ungdom. Bortset derfra blev det dog gennemf $\phi$ rt efter planen, det varede i 10 dage, blev ledet af social-psykologen Gunnar Hjelholt. Der var 
40 deltagere, hvoraf 10 var stofmisbrugere i behandling, 6 var alkoholister fra Louisestiftelsen i Sor $\phi$, 5 var stabsmedlemmer. Yderligere deltog en gruppe studerende fra Århus Børneforsorgsseminarium, og resten var tilknyttet Ungdomskliniken.

Da der endnu ikke foreligger rapport om minisamfundet, er det vanskeligt at give en endelig vurdering af dets betydning. Det umiddelbare indtryk er dog dette, at der heri ligger nogle muligheder, som absolut må gennemprøves. Det er blandt anden måden at være sammen på, ansvaret ikke alene for sig selv, men også for gruppen og i sidste instans for det lille samfund. Det er en form for behandling, som ikke er behandling i traditionel forstand. At der var problemer og konflikter, både i den enkelte husgruppe og i samfundet som sådant, var åbenbart, og at nogle af disse problemer ikke nåede at blive løst på en hensigtsmæssig måde, som f. eks. et for voldsomt alkoholforbrug, skal ikke skjules. Men dette til trods var fors $\varnothing$ get tankevækkende og inspirerende.

Der er ikke i denne artikel blevet nævnt noget om den lægelige behandling af unge stofmisbrugere. I samtlige behandlingssystemer indgår læger, som oftest psykiatere, som et naturligt og uundværligt led i medarbejderstaben. Nogle behandlingssystemer overlader afgiftning eller nedtrapning til sygehusene og statshospitalerne, medens andre som f. eks. Ungdomskliniken kun i særtilfælde foranlediger hospitalsindlæggelse alene med henblik på nedtrapning.

Men da artiklen i $\varnothing$ vrigt ikke indeholder funktionsbeskrivelse af andre faggrupper som f. eks. socialrådgiveren eller psykologen, ser jeg ingen grund til specielt at uddybe lægens rolle.

I behandlingen af unge stofmisbrugere indgår som oftest både et lægeligt, et socialt og et psykologisk aspekt, vægten kan være forskudt til den ene eller anden side, og dette må naturligvis tages $\mathrm{i}$ betragtning ved behandlingens tilrettelæggelse.

Men udover disse aspekter er der det samfundsmæssige aspekt, som er af meget stor betydning, fordi det ber $\phi$ rer vidt forskellige områder af problematiken. Kun nogle enkelte områder skal fremhæves.

For at g $\phi$ re noget for og sammen med stofmisbrugere kræver det steder at være i. Og det kan være meget svært, uanset om disse steder skal lejes eller købes, og uanset om det er i København, i provinsen eller på landet. Det er ikke et problem, der specielt har at g $\phi$ re med stofmisbrugere, det gælder faktisk alle afvigere - eller mindretalsgrupper. Der er næsten ingen, der vil acceptere eller er positivt indstillet over for tanken om, at grupper med enten fysiske eller psykiske handicap eller med andre problemer skal være i deres umiddelbare nærhed. Vi har læst om 
protestskrivelser over for åndssvages, spastikeres, epileptikeres anbringelse i normale milj $\phi \mathrm{er}$, og det samme gælder for alkoholister, kriminelle, stofmisbrugere. Det er klart, at det kan medf $\phi$ re problemer i nabolaget, og det er forståeligt, at der reageres imod dette. På den anden side er det $\mathrm{i}$ dag tendensen inden for behandlingssektoren så lidt som muligt at anvende lukkede og afspærrede institutioner og $\mathrm{i}$ videst muligt omfang at behandle $\mathrm{i}$ det normale milj $\phi$.

Et andet område, der skal nævnes, er spørgsmålet om samfundets vilje og muligheder for at modtage og integrere stofmisbrugerne, når de er i stand til at forlade de beskyttede miljøer. Kan de få et rimeligt sted at bo? Vil de blive accepteret og optaget $\mathrm{i}$ andre ungdomsgrupper? Kan de få arbejde eller uddannelse inden for områder, som de ud fra et realistisk synspunkt kan klare både fysisk og psykisk, og som de samtidig kan opleve som meningsfyldt, i hvert fald mere meningsfyldt end en fortsat tilværelse som stofmisbruger?

Der er mange andre områder, naturligvis, som har at gøre med vor samfundsstruktur og vort stofmisbrugsproblem. Og ser vi på det som et generelt problem, hvor stofmisbruget må betragtes som et symptom, der delvis kan dække over de bagvedliggende psykiske, sociale og samfundsmæssige problemer, så er det for mig klart, at vi ikke kan behandle os ud af dette problem. Der må stadig være muligheder for at hjælpe den gruppe, der er kommet så langt ud, at de ikke selv kan klare at komme tilbage igen, eller som måske kan hjælpe med til at fremskynde en spontan helbredelsesproces. Men det egentlige arbejde $b \phi r$ nu koncentreres om præventionen, og dette involverer $\mathrm{i}$ videste forstand familielivet, børneopdragelsen, skolen, fritiden, uddannelse og arbejde. Vi må se på at prøve at forbedre de enkelte menneskers muligheder for at „leve“ i vort samfund.

Karen Berntsen

\section{LITTERATUR}

Karen Berntsen: Tilbud til Stofmisbrugere. Ungdomsklinikens behandlingseksperiment. Christian Ejlers' forlag. København. 1971.

H. H. Brydensholt: Narkotika og Straf. Juristforbundets forlag. København. 1971.

Nils Christie: Narkotika. En rapport fra Verdens Helseorganisasjon. Pax forlag. Oslo.

Karl Evang: Aktuelle Narkotikaproblemer. Tiden Norsk Forlag. Oslo 1967. Samme bog på dansk: Narkotika - Kortene på Bordet. Fremads Fokusbøger. København. 1968. 
Boje Katzenelson: Stofproblemer. Bruger og behandling. Socialpædagogisk bibliotek, Munksgård, København, 1973.

Erik Manniche, Bjørn Evald Holstein \& Merete Watt Boolsen: En empirisk og teoretisk analyse af stofbrug blandt unge på Bornholm 1972. Rapport fra kontaktudvalgets forskningsunderudvalg. København. Juli 1972.

Erik Manniche, Bjørn Evald Holstein \& Merete Watt Boolsen: Stofbrug blandt skoleungdom i Roskilde 1972. Rapport fra kontaktudvalgets forskningsunderudvalg. K $\phi$ benhavn. September 1972.

Narkotikaforskning. Nordiska Rådet. Nordisk udredningsserie 11/70. Stockholm. 1970.

Kontaktudvalget vedrørende ungdomsnarkomanien. Redeg $\varnothing$ relse II om visse sider af stofmisbrugsproblemets udvikling og forslag til påtrængende foranstaltninger. København. September 1970.

Kontaktudvalget vedrørende ungdomsnarkomanien. Redeg $\varnothing$ relse III om prævention af stofmisbrug. København. April 1972.

Socialstyrelsen, Stockholm: Behandling av narkotikamissbrukare. Del 1 og del 2.

Stofmisbrug. Orientering for lærere og ungdomsledere, forældre og unge - om euforiserende stoffer. Komiteen for sundhedsoplysning. København. Januar 1969.

Tage Voss og Marianne Ziirsen: Stofmisbrug - en samfundssygdom. Thaning \& Appel. København. 1971.

Jens Windsl $\phi w$ : Ungdom og stofbrug. Paludans Fiol-bibliotek. Jørgen Paludans forlag. København. 1972. 